\title{
A STUDY ON THE RECONSTRUCTIVE SURGERY OF THE MIDDLE EAR
}

\author{
I Volume: Clinical Observation
}

Especially About Clinical Analysis on Constitution of Sound Conduction

\author{
By \\ SADATAKE KOBAYASHI
}

From the Depertment of Oto-Rhino-Laryngolog. Nippon Medical School

(Director: Prof. Y. Hashimoto)

The author observed analytically 485 ears to which reconstructive surgery was performed for past ten years, especially about remained ossicles and various columella. Results as follows:

1) These cases were divided into two groups: till 1960 and after 1961. In the first group, type IV were 61/213, repairment of ossiclar joint and use of columella were $13 / 213$, but in the second group, the former were $6 / 272$, the latter were $108 / 272$.

2) Type I: There were no remarkable findings except the post operative adhesion.

3) Type II: When the incudostapedial joint was invaded organically, the post operative hearing was worse in rate of hearing improvement than normal. In these cases, it is necessary to repair or reconstruct the joint with connective tissue, artificial prosthesis and adhesive agent.

4) Type III: When the function of stapes was normal, the post operative hearing was suc. cessful, however when the stapes was invaded high degree, preferably columella should be utilized.
5) Type IV: Generally the post operative results of this type were unfavorable, then colu. mella should be utilized actively.

6) Use of various columella: As columella, non-pathological auto-ossicle was the most effective as regards post operative course. When it was no avairable, the artificial columella should be utilized, and it was desirable that the artificial columella was light, easily shapable and have adaptable elasticity and moreover did not cause foreign body reaction. The author has utilized polyethylene and nylin-tube, and did not find any remained lesion evidently.

7) Post operative adhesive process: When the various adhesive process disturbed the sound conduction, it was necessary to prevent from adhesion by not only adaptable procedure but also various antiadhesive medicaments. Finally the author emphasized that it should be further more study on ossicle, protshesis and adhesion from pathological and physiological point of view.

\section{聴力改善手術に関する研究}

第 1 編 陪床的㓋察（特に伝音構成の臨床的分析）

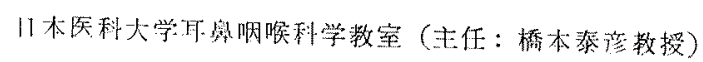

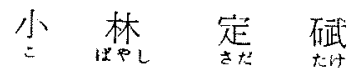

\section{目次}

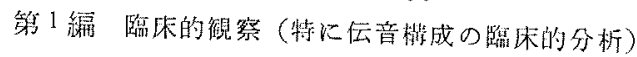

第了章緒要

篇』章研究効象及び方法
第 1 筑 研究詨象

第 2 穊 破究力法

第 III章 研究成露

第1節 絰合成緙 
第 2 節 Wullstein の养類及びその他の各型に就 Wr

a Wullstein I 型例に就いて

b Wullstein \|型例に就いて

c Wullstein 型例に就いて

d Wullstein N 型例に就いて

e 耳小骨連鑜修復成形及び支枉(コルメラ) 使 用例に就いて

第 N 章 プロテーゼ（支柱即ちコルメラ）に就いて

第 V章 絰括並びに考按

a 中耳特に耳小骨の病変及びその处圆に就いて

b 中耳の厷音機棈との関係に就いて

c 支柱（コルメラ）使用に就いて

$\mathrm{d}$ 手術例 检討

第朾章 結諭

参考交献

\section{第I章 緒 言}

中耳の器質的病変及び異常と艺机による伝音障㶳に対 しては，古来より保存的療法と共に手術癔法が行われ，

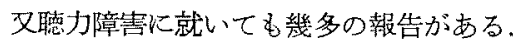

即万侻来この伝音系の病变主として慢性中耳炎に対し ては所謂根治手術が行われていたが，この手術法は術後 聴力が不良であつたため Neumann (1928), O. Mayer (1929) Kより術後の睦力損失を防ぐため手術時豉室及 び耳小骨連鎖を可及的に保存する方式として，半根治手 術（聴保根治手術, 保存的根治手眞) が施行された。し かしこの術式は従来の根治手術に比し病変の程度及び部 位により中耳,病变の除去が往々不充分な恐があり，特に

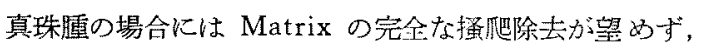
このため病変の再発が時に認められ又手術の滴応にも 限界が生じてきた。

これら不備の点を補い且つ中耳病変の完全除去と積

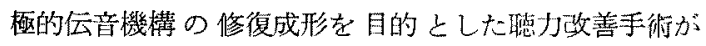
Moritz (1950) Zöllner (1951) Wullstein (1952) 等 に上り工夫考案され良好な成果索得るに至つた。これは 近時の抗生物質療法，化学療洼の発達に上り合话症を汸 止し術後治療を容易にならしるたのみならす，更に手術 操作の広沉且つ微細化，程極化を可能にしたためと思わ 独。

更に1953年 Zeiss の手術用影证鏡の完成により術操 作の精密確奏化が一段上すす又又耳科手術に更に高度の術 式が考案され現在の Otomicrosurgery の進步をきたし たと考えられる，乙の術式は理論的には Wullstein の
分類によるI〜V型に要約される．しかしこの分類によ る瀶床上の応用は多数の手衡庭例より見ると必ずしも理 諭と実際との合致を見ず，その適应及び術式も更に搪 大されつつある現沇である。

この Wullstein の分類によると【型】型に比し四型 V 型及び V型が施行される場合は，中耳の病变高度で特

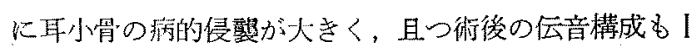
型』型が比較的正常状態に近いのに比し，様々な制約を うけ術後聴力はI型型には及ばない。そこで耳小骨連 鎖の各種の補修成形や，支柱（Strut, columella 以下

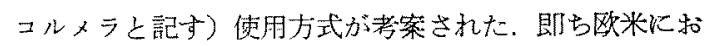
いては, Hall \& Rytzner (1957) の残存耳小骨による コルィラ利用, Heermann (1962) の軟骨コルメラ, Maatz, Bauermeister (1962) の異種組織 コルメラ, Shambaugh, House, Goodhill, Cawthorne, Guieford, Lindsay, Austin, Goldmann, Schuknecht, etc. の人 Iニルメラ等があり，又本邦に拈いては徯藤（修）、風 閒，高原，解田，黑住，橋本，中村（四）等のbのが女 る.

莑者の教室に机いても聴力改暃手術及びそれに関連す る研究は 10 数年来繼続し今日に至つているが，この研 筑の一環として効果的聴力政善手術の奏態を把握する目 的を死つて, 臨床的, 病理組織学的研究儿就いて統計的 並びに䋁合的钼察を行ら哥に上り，中耳内病的機構の修 復にあたりより良好な伝音構成を得るためには，合目的 手術操作と共に術後の慎重な治療が必要である牙が判明 した。即ち術時可能な限り耳小骨を残存させ良好な伝音 構成の保持を計る事，又それが不可能の場合にはコルメ

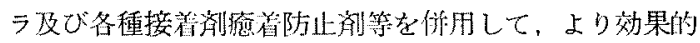
な伝音構成を工夫し術後絽過の安定を計る事である。

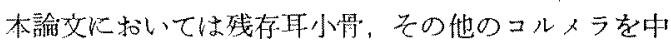
心として臨本的に分析を加之，いかにすれば良好な伝音

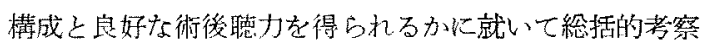
を試みた。

\section{第 II章 研究対象及び方法}

第1節 研究刘象

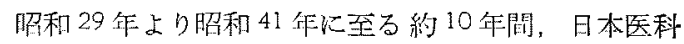

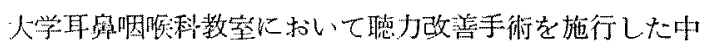
で資料上価值ある 485 耳を対象とした。症例数は 441 症 例, 内, 舅: 243 例, 270 耳, 女: 198 例, 215 耳で, 嵌 例の年令忧6才から53才迄に及几でいるが大部分は20 才前後であつた。

第2節 研筑方法

往来のWullstein の分類に順して行われた炤和 35 
年迄の症例と，著者の教室における方式が多く適応され た炤和 36 年以後の症例亡に分類し，各々をWullstein の分類に順ずるもの及び順じないるのとに分け，後者は その術式に応じて分類した。この各分類に従つて術後聴 力と耳小骨との関係を中心に観察し，又伝音系難聴例に 対寸る手術的分類，中耳及び耳小骨の病变の程度，残存 の可否，コルメラの工夫等の他，その病態に関連する介 在菌，耳漏の状態，植皮弁等の関係に就いても併せて観 察した.

\section{第 III 章 研 究成績}

第 1 節 総合成績

炤和 29 年末より昭和 41 年初め迄の 485 耳を Wullstein (以下 W. と略す) の分類 ( $1 \sim$ V型)，耳小骨連 鎖補修成形及び各種ュルィラ使用例に分類した，交の例 数及び\%に就いては表1の如くである.

表 1 全手術例の分稹

\begin{tabular}{|c|c|c|}
\hline $\begin{array}{l}\text { W.によ る } \\
\text { 類及びその他 }\end{array}$ & 例 数 & $\%$ \\
\hline 型 & 29 & 5 \\
\hline 型 & 207 & 43 \\
\hline 型 & 57 & 12 \\
\hline 琹 & 74 & 15 \\
\hline 型 & 4 & 1 \\
\hline $\begin{array}{l}\text { 平小骨連鎖博修成形 } \\
\text { 及びュルメラ使用 }\end{array}$ & 114 & 24 \\
\hline 訫 & 485 & \\
\hline
\end{tabular}

W. II 型に就いては，耳小骨連鎖に 手術操作を全く加 え呚の久とし，キヌターアブミ関節補修成形例は耳小 骨連鎖補修成形例飞入れた。

全手術例中 W. II 型施行例が最も多く約 $43 \%$ ， つ

表 2 沼和 35 年迄と昭和 36 年以後の比較

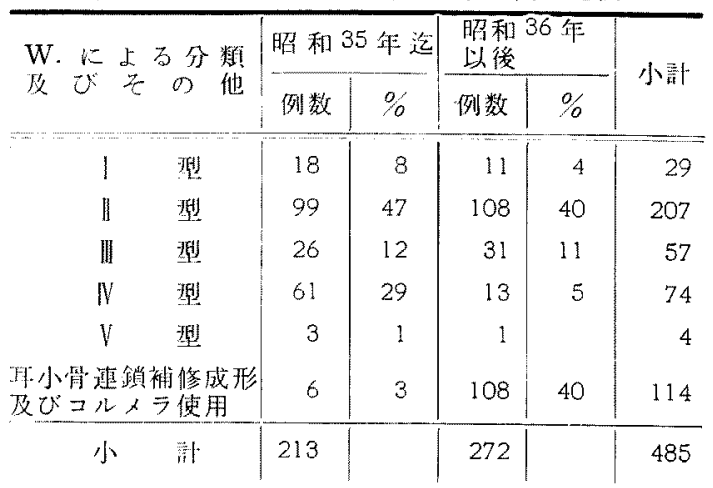

で耳小骨連鎖補修成形及びニルメラ使用例が $24 \%$ ，次 いで W. V 型の順である. しかしこれを昭和 35 年迄と 昭和 36 年以後々に分け検討すると表 2 の如くなる.

即ち表 2 の. 1 吕 型例汇就いては，昭和 35 年迄 之昭和 36 年以後の症例の比率には著変は認められない が，W. N 型例㶤就いては，前者は $29 \%$ と全例の約 $1 / 3$ を占めるに比し後者はわず $5 \%$ にすぎない，これに反し 耳小骨連鎖補修成形例及びュルメラ使用例では前者が $3 \%$ であり後者が $40 \%$ と增加している．これは第一飞昭 和36年頃上り耳小骨連鎖不全例，主としてキヌターフフ 乏関節不全例比対して積極的儿補修成形が加えられしか むW. I型例に順ずる良好な術後聴力を得る努力がな された事と，第二に W. N 型例の術後聴力が W. I 型 及び】型例に比し些か劣るために更に耳小骨伝音機構を 成形すべく種々のコルメラ方式が工夫利用された結果と 考党られる。

第 2 節 W. の分類及びその他の各々に就いて

a) W.I型に就いて

これは耳小骨及びその連鎖全く健全なるの故，その機 能という点では癒着丈が問題となり, 術後瘉着と推定さ れる不成功例を 1 例認めたにすぎなかつた。この症例は ッチ骨とリビニー切痕間の癒着と考えられたが，これら 癒着は術時の注意と適切な処置（癒着防止剤の使用等） で充分防止できるるのと思われる。

b) W. 『型に就いて

一般に W. II 型が施行される症例は中耳腔の殆んど は乾燥し炎症性変化の消退している W. I 型に比し， 術前の病変が W. I 型上り高度であるため, その種類上 程度が問題となる。即ち肉芽の有無多寒, 真珠䡍の有 無，及び仏がりの程度，又局所が乾燥しているか，湿洞 しているか，それとも耳漏を認めるか等である。

W. II 型施行例を検討すると耳镜処見で乾燥及び乾燥 に順ずるもの $40 \%$ ，この内 $2 / 3$ は手術時処見で中耳腔 は殆んど乾燥し癒着㑯向を示したにすぎなかったが，残 りの約 $1 / 3$ には手術時中耳腔に少量の肉芽あるいは真珠 腫が認められた。

耳鏡処見で湿潤型のものは30\%で大部分は手術時肉 芽あるいは真珠腫を認めた，残り30\%は中等量の耳漏 （耳鏡で耳漏を認めるも外耳道上り常時流出しない程度） が存在し手術時耳小骨の一部から殆しど埋没する肉芽及 び真珠腫が認められた。，又細菌相に就いてはグラム陰性 の桿菌が最も多く，葡萄球菌がこれについで多かつた。 これら練荣の感受性に就いてはグラム陰性の桿菌は抗生 
物質に抵抗を有するものが多く，比較的ストレプトマイ シン, カナマイシン, グラム陰性桿菌に有効な抗生物質 及び合成抗菌郕が有効であつたにすぎない，葡萄球菌に 就いては，他部より検出したものより耳漏中のものの方 がやや抗生物質に抵抗性を示していたが，広スペクトル の抗生物質は有効であつた.

W. II 型施行例は術前の諸恰查之手術時の処見とを考 慮して耳小骨を残存せしめ，且つ術後その機能が良好比 保持されると推定して施行されたが，その際肉芽又は真 珠腫存在例は可及的に除去し且つ耳小骨の被膜の保存に 務め栄盖血管の障害を可能な限り少なくし術後の再発や 破壊吸収の防止を計つた，しかしこの上らな処置で良好 な経過をとるものと推定されるに拘らず，時に聴力改善 不良例も認められた。この原因は病变を受け易いキ又 ターフブミ関節が関与しているものと推定されるので, W. II 型例に就いては特にキヌターアプミ関䬦を中心に その病態について分類すると表 3 ，表 4 の如くなる。

表 3 ,表 4 共にキヌターフブ ミ関節不全例の術後聴力は

表 3 昭和 35 年迄の W. II 型施行例 (99 例)

\begin{tabular}{|c|c|c|c|c|}
\hline $\begin{array}{l}\text { キヌターフブ } \\
\text { ミ関節 }\end{array}$ & 例数 & $\begin{array}{l}\text { 術後会話域の相 } \\
\text { 加平均㯖力 }\end{array}$ & 例数 & $\begin{array}{l}a \dot{z} b \\
\text { の割合 }\end{array}$ \\
\hline 関 節 健 全 & 68 & $\begin{array}{l}\text { a) S.L. 内 } \\
\text { b) S.L. 以下 } \\
\text { c) 混合系難聴 }\end{array}$ & $\begin{array}{r}53 \\
15 \\
0\end{array}$ & $\begin{array}{l}78 \% \\
22 \%\end{array}$ \\
\hline $\begin{array}{l}\text { 関節存在する } \\
\text { 結合織肉茅 } \\
\text { で被われてい } \\
\text { るすの }\end{array}$ & 21 & $\begin{array}{l}\text { a) S.L. 内 } \\
\text { b) S.L.以下 } \\
\text { c) 混合系難聴 }\end{array}$ & $\begin{array}{r}14 \\
6 \\
1\end{array}$ & $\begin{array}{l}70 \% \\
30 \%\end{array}$ \\
\hline $\begin{array}{l}\text { 関節離断し結 } \\
\text { 合織で等で結 } \\
\text { しているもの }\end{array}$ & 10 & $\begin{array}{l}\text { a) S.L. 内 } \\
\text { b) S.L. 以下 }\end{array}$ & $\begin{array}{l}6 \\
3\end{array}$ & $\begin{array}{l}67 \% \\
33 \%\end{array}$ \\
\hline
\end{tabular}

註 表3,4,5,6,の S.L. は Social lebel の略

表 4 炤和 36 年以後のW. 【型施行例 (108 例)

\begin{tabular}{|c|c|c|c|c|}
\hline $\begin{array}{l}\text { キヌターアブ } \\
\text { 関節 }\end{array}$ & 例数 & $\begin{array}{l}\text { 術後会話域の相 } \\
\text { 加平均聴力 }\end{array}$ & 例数 & $\begin{array}{l}a \frac{k b}{a} \\
\text { 嗐合 }\end{array}$ \\
\hline 関 節 健 全 & 83 & $\begin{array}{l}\text { a) S.L. 内 } \\
\text { b) S.L. 以下 } \\
\text { c) 混合系難聴 }\end{array}$ & $\begin{array}{l}61 \\
12 \\
10\end{array}$ & $\begin{array}{l}83 \% \\
17 \%\end{array}$ \\
\hline 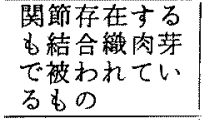 & 15 & $\begin{array}{l}\text { a) S.L. 内 } \\
\text { b) S.L. 以下 }\end{array}$ & $\begin{array}{l}10 \\
5\end{array}$ & $\begin{array}{l}67 \% \\
33 \%\end{array}$ \\
\hline 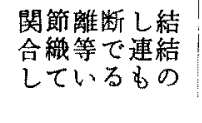 & 10 & $\begin{array}{l}\text { a) S.L. 内 } \\
\text { b) S.L. 以下 } \\
\text { c) 混合系難聴 }\end{array}$ & $\begin{array}{l}6 \\
3 \\
1\end{array}$ & $\begin{array}{l}67 \% \\
33 \%\end{array}$ \\
\hline
\end{tabular}

関節健全例に比し不良であつた。一般にキヌターアブミ 関節健全例は耳小骨自体も健全な例が大部分であるに 比し，関節不全例は耳小骨自体にも病変のある事が多い

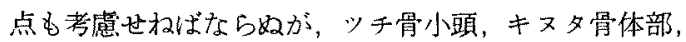
アブミ骨は再手術例を検討しても比較的健全に保持され ている事が多く，関節健全例と不全例に打ける術後聴力 改善率は，昭和 35 年迄怔前者 $78 \%$ 後者 70\%，昭和 36 年以後は前者 $83 \%$ 後者 $67 \%$ と約 $10 \%$ の差が認められる がここれはキヌターアブミ関節不全が主因と考党られる。 換言寸ればキヌターアブミ関節不全例に执いて 良好な 経過をとるむのと期待して手術時残存放置したために健 全例に比し 10\%前後の差で術後関節不全といら伝音構 成の障害を残したものと推定される，更にこの事は後述 のキスターフブミ関節不全例に対して関節補修成形を 行つた 12 症例中 11 症例が好結果を得ている事加らも蔓 付され得る。

C） W. III 型施行例泟就いて

W. II 型施行例は W. I型のもの占りも一般飞病变 高度な場合が多く，又再手術例も多いが細菌相及び抗生 物質に対する感受性に訊いては著変はなからた。

W. III型は残存耳小骨としてはアブミ骨のみなので, この残存アブミ骨が健全か変形，萎縮，変位，又結合織 肉芽に埋没しているか，更にアブミ骨に手術操作を加え たか等の点について分類すると表 5 ，表 6 の如くにな る。

表に示されている如くフブミ骨健全例に比し萎縮，変 形、变位及び肉芽結合織に埋没したものや，卵円空に固 着文陷仙して手術操作を加之たるのは，術後聴力は不良 であつた. 又昭和 35 年迄と昭和 36 年以後との間にも差 があり，後者の方が術後聴力は良好であつた。

表 5 昭和 35 年汽のW. 目型施行例 (26 例)

\begin{tabular}{|c|c|c|c|c|}
\hline フブミ骨 & 例数 & $\begin{array}{l}\text { 術後会話域の相 } \\
\text { 加平均聴力 }\end{array}$ & 例数 & $\begin{array}{l}a \frac{k b}{b} \\
9 \text { 割合 }\end{array}$ \\
\hline 健 & 18 & $\begin{array}{l}\text { a) S.L. 内 } \\
\text { b) S.L.以下 } \\
\text { c) 证合乐難聝 }\end{array}$ & $\begin{array}{r}10 \\
6 \\
2\end{array}$ & $\begin{array}{l}63 \% \\
37 \%\end{array}$ \\
\hline 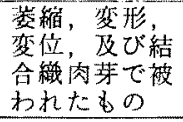 & 4 & $\begin{array}{l}\text { a) S.L. 内 } \\
\text { b) S.L. 以下 }\end{array}$ & $\begin{array}{l}2 \\
2\end{array}$ & $\begin{array}{l}50 \% \\
50 \%\end{array}$ \\
\hline $\begin{array}{l}\text { アブミ骨に手 } \\
\text { 術操作を加え } \\
\text { たもの }\end{array}$ & 4 & $\begin{array}{l}\text { a) S.L. 内 } \\
\text { b) S.L. 以下 } \\
\text { c) 浔合系難聴 }\end{array}$ & $\begin{array}{l}1 \\
2 \\
1\end{array}$ & $\begin{array}{l}30 \% \\
70 \%\end{array}$ \\
\hline
\end{tabular}


表 6 昭和 36 年以後の W. III型施行例 ( 31 例)

\begin{tabular}{|c|c|c|c|c|}
\hline アブミ骨 & 例数 & $\begin{array}{l}\text { 䔎後会話域の相 } \\
\text { 加正均聴力 }\end{array}$ & 例数 & $\begin{array}{l}a k b \\
\text { 割台 }\end{array}$ \\
\hline 全 & 18 & $\begin{array}{l}\text { a) S.L. 内 } \\
\text { b) S.L. 以下 } \\
\text { c)混合系難㯖 }\end{array}$ & $\begin{array}{r}12 \\
3 \\
3\end{array}$ & $\begin{array}{l}80 \% \\
20 \%\end{array}$ \\
\hline 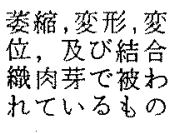 & 9 & $\begin{array}{l}\text { a) S.L. 内 } \\
\text { b) S.L. 以下 } \\
\text { c) 混合系㩲聴 }\end{array}$ & $\begin{array}{l}3 \\
2\end{array}$ & $\begin{array}{l}57 \% \\
43 \%\end{array}$ \\
\hline $\begin{array}{l}\text { アプミ骨に手 } \\
\text { 城操作を加克 } \\
た も の\end{array}$ & 4 & $\begin{array}{l}\text { a) S.L. 内 } \\
\text { b) S.L. 以下 } \\
\text { c) 混合系難㯖 }\end{array}$ & $\begin{array}{l}2 \\
1 \\
1\end{array}$ & $\begin{array}{l}679 \\
339\end{array}$ \\
\hline
\end{tabular}

W. 【型施行例化就いてはアブミ骨が健全な場合は昭 和 36 年以後の結果で示されれている如く最近の手術操作 の進歩で可成の好結果が期待できるが，不全例飞就いて は術後のアブミ骨の経過を充分考慮する必要がある。

即ちこの事は昭和 36 年以後の不全例及び 手術操作を 加えたるのが昭和 35 年迄の例上り良好な結果を得てい る事からも，手術時の耳小骨の処見とそれに対する処置 が適切であつた事索示して垎り。これらの事からも不全 アブミ骨に対しては，そのアブミ骨の生活力と機能，術 後経過等を考慮娭討し慎重に処理すべきである。

d) W.N 型施行例儿就いて

昭和 35 年迄上昭和 36 年以後の各々の術後㯖力に就い て比較すると表 7 の如くなる。

\section{表 7}

\begin{tabular}{|c|c|c|c|c|c|}
\hline (61) & & & $\left(10\left[\mid B_{1}\right)\right.$ & & \\
\hline & 例数 & $\%$ & $\begin{array}{l}\text { 衍後会話域の相 } \\
\text { 加装均聴力 }\end{array}$ & 例数 & \\
\hline & 1 & 6 & $30 \mathrm{~d}$ & & 31 \\
\hline$a b$ & Y & 15 & $40 \mathrm{db}$ & & \\
\hline & 22 & 36 & & & 15 \\
\hline & 14 & 23 & 㯖 & 6 & \\
\hline
\end{tabular}

炤和 35 年迄の W. N 型施行例怜全例の $28 \%$ であるに 比し昭和 36 年以後はわずか $5 \%$ にすざない，即古昭和 36 年以後は W. V 型に対し棈極的にコルメラ力式が利 用されな結果である。後述の如くこの結果術後聴力に関 しても W. N 型例上り良好な結果を得ている。

一般炕 W. N 型施行例は病変高婓であり，又根治手 術後等の再手術例が多く且つ队耳空の機能障害が介入す
ることも考えられ，伝音並びに感音機能間の微妙な関係 として今後更に検討すべき多くの問題を残している。

e）耳小骨連鎖補修成形及び人工コルメラ使用例飞 就いて

耳小骨連鎖を中心とする伝音機構の補修成形例及びさ ルメラ使用例は昭和 35 年迄には 6 例 $3 \%$ のみであるが， 昭和 36 年以後は 108 例 $40 \%$ に及几でいる，即ち前者6 例とは，キヌタ骨をずらし長脚残存部をアブミ骨汇接 合させたもの (Incudostapediopexy 図1a)1例で術 後会話域相加平均聴力（以下術後聴力之略す） $41 \mathrm{db}$, キ ヌ夕骨を除去しッキ骨とフブミ骨を接合させたすの (Malleostapediopexy 図 2 a イ) 2 例で術後聴力 $45 \mathrm{db}$ ， $36 \mathrm{db}$ ，ッ手骨唡部骨折し Malleostapediopexy つたもの（図 $2 \mathrm{a}$ 口）1 例で術後聴力 $23 \mathrm{db}$, 結合䢂を卵 円空と皮弁の閂に介在させたもの（図 $5 a$ ）1例で術 後聴力 $33 \mathrm{db}$ ，アブミ骨欠損例にポリェチレンュルx ラを使用したもの（図 4b) 1 例で術後聴力 $29 \mathrm{db}$ ，以 上半数の3例の及が良好な結果を得たにすぎなから た、これて対し昭和 36 年以後を分類すると表 8 の如く なる。

表 8 昭和 36 年以後の耳小骨操作及びュルメラ 使用例 (108 例)

\begin{tabular}{|c|c|c|}
\hline & 分 & 例 数 \\
\hline & 1、キヌターアプミ関節補修成形（図 1) & \\
\hline $\boldsymbol{T}$ & $a$ キヌタ骨を下へずらす（図1 a ) & 9 \\
\hline ブ & $\mathrm{b}$ 自家組織十接着剤（図 $1 \mathrm{~b}$ ) & 12 \\
\hline इ & 2、ツチ骨アブミ骨接合（図2) & 10152 \\
\hline 管 & Malleostapediopexy & \\
\hline $\begin{array}{l}\text { 存 } \\
\text { 在 }\end{array}$ & 3、キヌタ骨アブミ骨接合（图 2) & 11 \\
\hline & $\begin{array}{l}\text { 4. ポリエチレン細管をアブミ骨頭部に } \\
\text { 恃めこさ (因 } 3 \text { ) }\end{array}$ & 10 \\
\hline & 5.ッチーキヌタ関節を保持しキスタ䯚 & 3 \\
\hline 方全 & 長脚を卵円空に接着（図 4 a) & \\
\hline 骨热 & $\begin{array}{l}\text { 6. ツチ一キヌタ関節を保持しキヌタ骨 } \\
\text { 長脚にポリエチレン細管コルメラ } \\
\text { (図 4b) }\end{array}$ & 2 \\
\hline 頭 & 7.ッチ骨をコルメラに利用（図 5 a ) & 5 \\
\hline 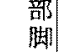 & 8.キヌタ䯚をコルメラに利用（図5b) & 536 \\
\hline 部 & 9. 自家組織をコルメラに利用（図6) & 2 \\
\hline 損 & 10. ポリエチン等人下コルメラ利用（図7） & \\
\hline 例 & a クロスパー付き & 17 \\
\hline & b クロスバー無 L & 21 \\
\hline & 他家組織をコルメラに & 1 \\
\hline & & 108 \\
\hline
\end{tabular}


これを術後㯖力に就いて 検討すると、アブミ骨牫存 52 例に就いての成績は次の如くで，(1) キヌターアブミ 閦節補修成形例は 21 例であつた，前述の如く昭和 35 年 迄は本術式のものは1例しかなく，他の関節不全例に就 いては術後関節機能が保持されることを期待し補修成形 を加えなかつたが，このため関節健全例に比し衡後聴力 改善率性 $10 \%$ 以上不良であり，この上うな関節不 全に対する処琶としてその後関節補修成形が行われた。 その術式としては

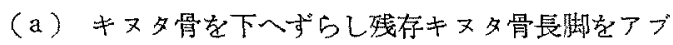
ミ骨に接合させたもの Incudostapediopexy（图1a) 9例，（b）キヌターアブミ関節を補修成形したもの， 即ち自家骨で補強し筋膜で被包したもの（図1 b イ）

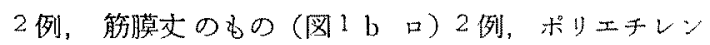

図1キヌターアブミ関節修復成形琎 昭和 36 年後 (21 例)

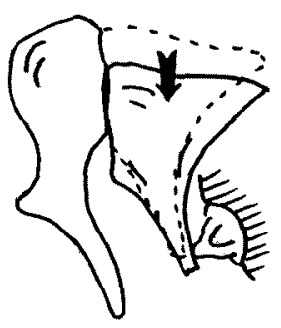

(a) キヌ多骨下へ

寸゙す ( 9 例)
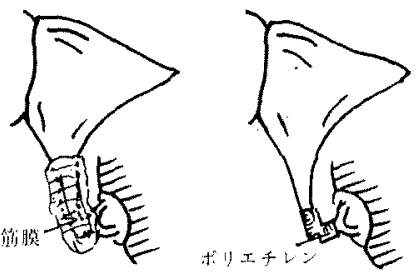

口 $(5|4|$ )
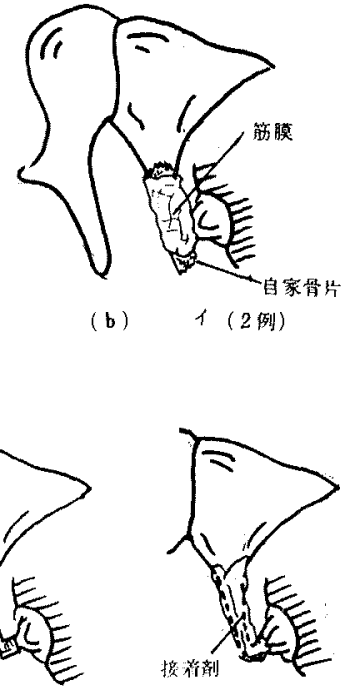

$=(3$ (刿) (b) 1 (2 例)

細管と接着郕で成形した6の（图１ｂ－、） 2 例，接着 郕丈で補强したもの（図l b の9 例中術後聴力 $30 \mathrm{db}$ 以内 5 例でこの大部分は筋膜で 被包したるのであつた。他の 4 例は $31 \sim 40 \mathrm{db} 2$ 例， $41 \sim 50 \mathrm{db} 2$ 例とあまり良い結果㥂られなかつたが， これは接合方法に不倩な点があつたか，接合が良好な経 過をららなかつたためと考光られる（b）の12例は耳

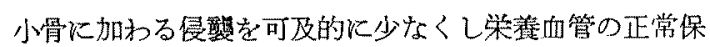
持を計り乍らキヌターアブミ関節を補修成形したるの

で，11 例は術後聴力 $30 \mathrm{db}$ 以内に達し前者の（a）の 万法占り良い結果が得られている。

(2) シチ骨アブミ骨接合所謂 Malleostapeúiopexy は（図 2 a) 10 例で術後聡力 $30 \mathrm{db}$ 以内は 5 例しかな く，これはンチ骨に術操作が加わり栄羡血管障害と接合 及びその機能不全によるるのと推定される。

图2ッチ骨アブミ骨接合
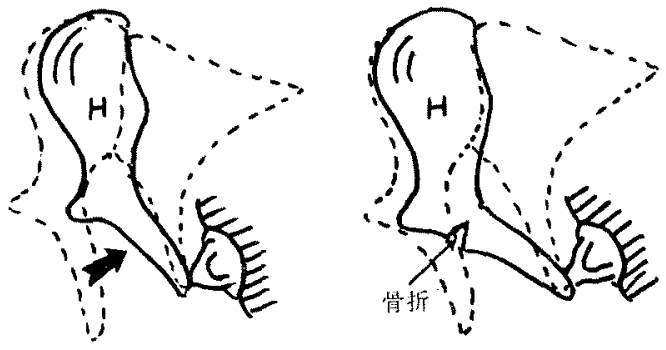

(a) 1 $\Gamma$

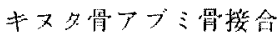

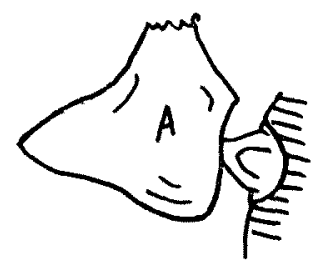

(b) 1

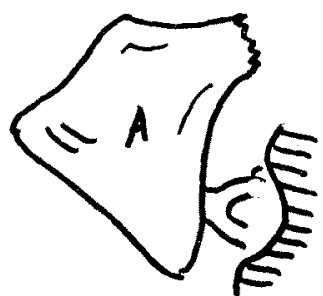

口

(3) ソチ骨を除さしギタ骨とフブミ骨を接合した Incudostapediopexy (図 2 b) 11 例で術後聴力 $30 \mathrm{db}$ 以内7例と、ソチ骬アブミ骨接合例上著恋はなくこの場 合もキヌ多骨の栄前血管障㕩と接合及びその機能不全が 推定される。

(4) 残存アプミ骨にポりエチレン細管人工コル×ラ を頭部にはめこみ，皮弁とアブミ骨の伝音程路を確保し

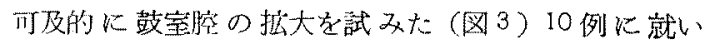

図 3

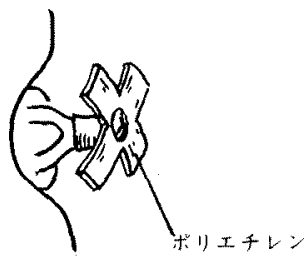

(10 例)
ては, 術後聴力 $30 \mathrm{db}$ 以内 のもの6例で，不成功例は 湦合性難㯖1 例を除 3 例 で $67 \%$ の成功率を収めて いる。

次ぎアブミ骨欠損 56 例 に就いては，アブミ骨の全 欠提のbのでなく頭部及び 
脚部の一部欠損したものが主である．即ち一般にアブミ 骨板久損寸る例は少なく，かなりの病変存在する症例で もアブミ骨板は存在しその機能消失するものは少なく， 且つ，た之点板欠損吸収されても粘膜，結合織残存骨等 により卵円空の補充機能を果していると考兄られるもの が多い。これらに対し卵円空，正円突の相互機能を確認 し各種コルメラを使用した。

（5）ッチ骨とキヌタ骨が残存し，ッチーキヌタ関節 を保持し作がらキヌタ骨長脚を卵円空に接着せしめたも の (図 4 a ) 3 例で, 術後聴力 $30 \mathrm{db}$ 以内のもの 2 例で

图 4

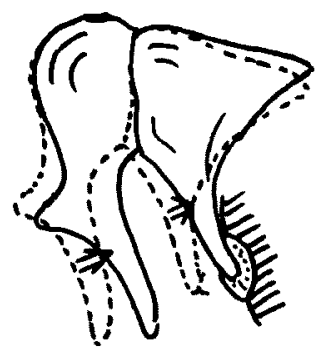

a $(3$ 例 $)$

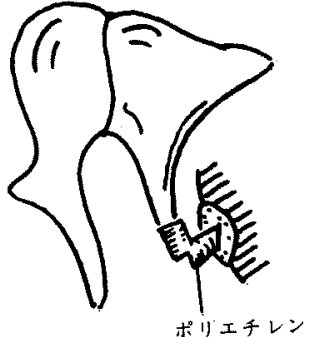

b (2 例)
他の 1 例は術前 $28 \mathrm{db}$ が術後 $50 \mathrm{db}$ と低下した。 こ の1例はキ又夕骨と卵円空の接着不全に上るむのと思わ れる。

（6）キヌタ骨長脚と卵円空の接合不全を補うために， 長脚先端に図 4 b の如くポリエチレン細管をアブミ骨 の代用として利用したもの 2 例で，共少後聴力 $30 \mathrm{db}$ 以内で好結果を得ている。

(7)，(8) ッチ骨及びキヌタ骨をコルメラとしたも ので，ッチ骨コルメラ（図 5 a) 5 例で術後聴力 $30 \mathrm{db}$ 以内 4 例，他の 1 例は混合系難聴であり，ッ千骨 コルメラは好結果を得たが，キヌタ骨コルメラ(図 5 b) は 5 例で術後聴力 $30 \mathrm{db}$ 以内 2 例と，ツチ骨ュルメ ラには及ばなかつた。ッチ骨キヌタ骨をコルメラとす る場合病変を除去しッチ骨，キ又合をコルメラとし て適切な形にし且つ安定な位置を保つためには耳小骨に 加わる手術操作は大きくなり栄養血管が障害されること になる。このような手術侵裂竖栄着障害が両骨に起り易 い位置的条件としては一般にはキヌタ骨の方が高度であ り，更にコルメラとして利用する場合一応摘出して形を 調整後再插置することもあるのでキヌタ骨に対する侵褧 はッチ骨より大である事は推定に難くない，従つて術後

図 5 ソチ骨キヌ多骨をコルメラに利用

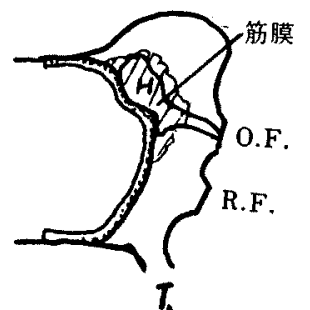

H:ツチ骨 $\mathrm{T}$ : 耳管開孔部

(a) 1

图 6 自家組織をコルメラに利用

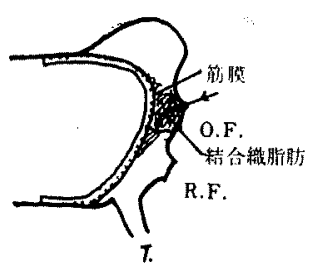

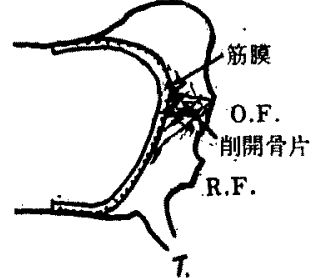

$\mathrm{b}$

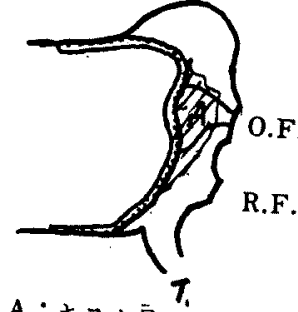

A：キヌ夕骨

(b)

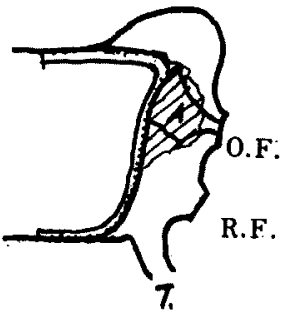

効果に大きな差が生じたものと思われる。

（9）自家組織をコルメラとしたもの（図6 a , b ) 即 ち自家調整骨片 1 例，脂肪塊之結合織并用 1 例，共衍 後聴力 $30 \mathrm{db}$ 以内であつた。

(10)人工材料主としてポリェチレン 細管(一部ナ イロン紐管)をコルメラとしための（図7) 38 例で， の内クロスバー付きのもの（図7写真中段）17 例， クロスバーのない8の (因7写真上段) 21 例. 前者の $5 ち$ 術後聴力 $30 \mathrm{db}$ 以内の6の 10 例， $30 \mathrm{db}$ 達世 ぬもの 7 例で内 2 例は混合系難聴で 5 例は不成功であ 
図 7

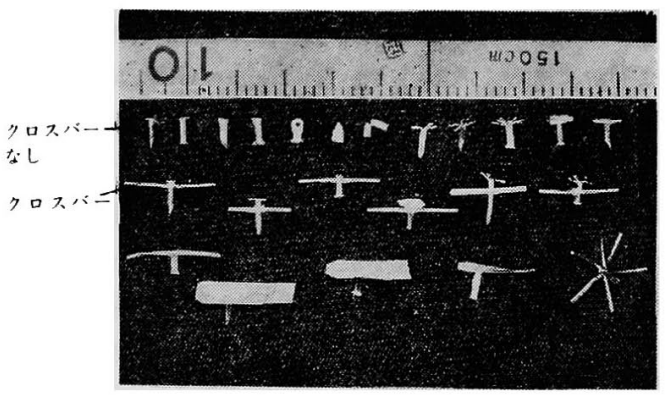

つた. 後者の5ち, 術後聴力 $30 \mathrm{db}$ 以内のもの 11 例, $30 \mathrm{db}$ に達せぬもの 10 例で内 3 例は混合系難㯖で 7 例 は不成功であつた，即ち成功例は前者 $67 \%$ ，後者 $60 \%$ とやや前者の方が良好であるが，なおかなりの不成功例 がありこれはコルメラ插置部位における不安定と組織反 応や病変の再発等が原因と思われる.

（11）異種組織所謂キールボーンをコルメラとした 1 例は W. II 型の再発例に対する再手術例で，局所の病 変高度であつたにも拘らず術後聴力 $30 \mathrm{db}$ 以内に改善 され長期間キールボーンによる異物反応は認められなか つた.

\section{第 IV 章 プロテーセ（支柱即ちコルメラ） 応用例に就いて}

第 四章の観察で述べた如く，昭和 36 年以後は耳小骨 連鎖機能不全例に対しては積極的にその補修成形が行わ れ，又耳小骨消失及び除去例に対しては W. IV 型より むしろコルメラ方式が利用され，昭和 35 年迄の W. IV 型例より好結果を得ている. しかしコルィラ使用時この 部位が聴力改善の点よりして Key area である故その 作成及び使用には一段と慎重な操作と高度の修練を必要 とすることは言ら迄もない、今後更にコルメラの応用に ついては拡大され進歩改良すべき多くの点が指適され る.

一般にコルメラの種類は次の 4 つに大別される.

(1) 残存耳小骨

（2）自家組織（自家削開骨片，軟骨，結合織，脂肪）

(3) 異種 組織

(4) 人工材料

以上の材料によるコルメラ作成の要件としては，（1） 局所に親和性があり組織反応の可及的に少ないもの, (2) 伝音構成上最も効果的で且つ永続的なもの, 安定が良いこと（術時，術後を含め），（4）質量小さく
適当な弾力撓力を有し細工し易いこと等である.

この要件で前記 4 種のコルメラに就いて考察するに,

(1) 残存耳小骨に就いて：局所に 親和性があるという 点ではすぐれているが術後の安定性という点では不安が 残る.（2）自家組織に就いて：親和性の点では良好で あるが前と同様術後の安定といら点で, な拉不充分で あり, 術後の経過中のコルメラとしての運命を想定して 詳細慎重な術式が必要である. 又軟部組織は弾性を欠く という点で難がある.

（3）異種組織に就いて：異物反応の無いものが望ま しいが,この点独乙の Kiel 大学の Maatz, Bauermeister 等により牛骨の軟部組織を融解処理し, 生物学 的性質を有し且つ免疫学的に刺㦸の少ないものが考案さ れ，所謂キールボーンと称されている．これは細工し易 く安定化も比較的容易であるが現在のところな拱物反 応が全くない完全なものとは言い難い.

（4）人工コルメラに就いて：これにはポリエチレ ソ, ナイロン, テフロン細管, 更にステンレススチー ル,タンタルムワイヤー文白金等がある.これらは初め外 科領域で使用され異物反応は殆んどなく術創部に比較的 良く順応することが実証され，耳科的にも利用されはじ めたもので細工が容易で質量が小さく適度の弾性を有し ているので最近大いに利用されている，しかし一部には 異物反応を認める例もあり未だ完全なものとは言へな い. 今後これらコルメラに就いては安定, 槓杆作用, 弾 力, 質量, 抵抗等の諸点で正常耳小骨連鎖に近いものの 出現が期待されている。

\section{第 V 章 総括並びに考按}

聴力改善手術は伝音機構の障害主として慢性中耳炎に 対し，その病変除去と良好な伝音構成のための補修成形 等により良好な聴力を得るための手術方式である.

第 四章の観察成績で述べた如く術後鼓室腔がより正 “常”状態に近いもの程聴力の改善及び保持が良く，伝音構 成の障害の程度が高度のもの程結果が好ましくなかつ た.しかし第 $N$ 章の各種コルメラ,プロテーゼ等の使用や

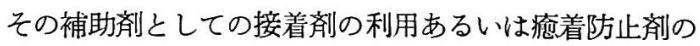
使用により一譄好結果を得ることが可能になつた。これ に反し好結果が当前期待されると思われたに拘らず聴力 の改善が得られぬ症例もあつた，その原因として，(1) 術前耳漏を認めた活動性病変の存在とそれに対する処置 の不備，（2）細菌相の種類と抗生物質に対する 感受性 が低いもの，(3) 局所に推定される抗原抗体の問題, (4) 術後処㯰の不適, (5) 術後再発, 感染, 癒着, 新 
生鼓膜の穿孔等，極めて多彩な因子が考光られるが，本

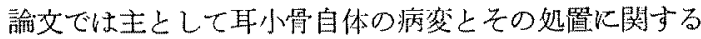
間題が伝音構成上最も重要である事を確認し得た。乙こ で耳小峝を主とする諸問題に関して詳述しようと思う。

a) 中耳特に耳愲の病紧及びその処圆に就いて

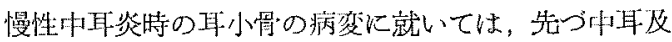

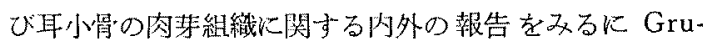
nert (1892) Ludewig (1890) の報告があるが，症例 数少なく詳細なものとは言い難い，井上（正）(1958) の慢性化膿性中耳资に対する研究は詳細な報告である。

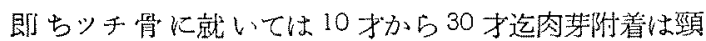
部前側に最も多くついで小䫓部に多い，又キ又夕骨に就 いては体部内側が最多多く外後側がこれに次ぎ長脚短脚

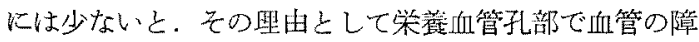

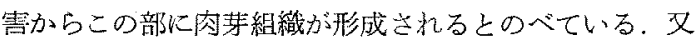

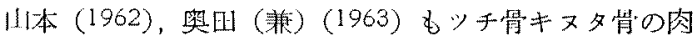
莱附着についてははぼ同様である，箸者の手術例では真

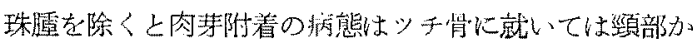
ら関節小頭部に最も多く，キ又多に就いては体部に

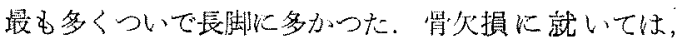
Grunert (1892), Ludewig(1890), Donalis (1897), 抹 上 (正) (1958), 山本 (1962), 奥田 (炼) (1963) に上 れば、ツチ骨では小頍部心最も多く，堀内(1935) は小 頭関節部に多いとし，茾上（正）(1958）はとの理由と して膿汁肉素のための栄荃血管の障害が原因で破潰欠 損すると。キヌタ骨では Grunert (1892), Donalis (1897), Manasse (1917), 井上 (正) (1958), 山本 (1962)，奥田（兼）(1963) 恃長脚に最も多く，堀内 (1935) はむし万短脚に多いと。井上（正）は去の理由

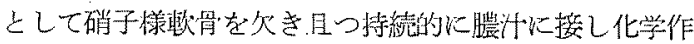
用をらけ破潰欠損するとのべている，著者の手術例では

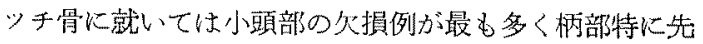
端部の欠損がこれについで多かつた。キヌタ骨に訧いて は前記諸家同嵄長脚の欠損が圧倒的に多くついで体部の 順であつた

ここで聴力改前手術に際し问及的に年小骨を残存せし め且つこれを活朋すること忪音棈成上最も望ましいこ とであるが，以上述べた諸病壆の存在に対し，いかにこれ

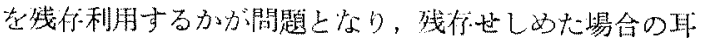
小管の生存能力については策養補給が最も重琶な事項て あると考えられる。即ち栄咅血管の障害が耳小骨の尰命 を左右するものであり，㹱つて手術㭙の保存か除去か以 も関係してくる. Lindemann (1963), Anson (1964) に
よれば耳小骨の栄養婊面の粘膜骨膜より内部に入る血 管によつて行われて和り耳小骨内部の主幹血管は直接に は栄責に関与しないとし，父 Nager G.T. and Nager， M. (1953), Hamberger and Wersäll (1953) 等Kよ りッチ骨キヌタ骨フブミ骨間にも血管を介する密接な関 係がある耕が認められている，従つて血管障害は耳小得 の残存に重大な影暗をさたす事は当然と票わねばならな い，そして耳小骨の栄荃が前述の如く骨被膜から補給さ れているとすれば，手術時耳小骨の粘䀦骨膜損傷は最小 限度に止めるべく慎重に取扱わねばならない，るし被膜 が除去されると耳小骨は異物となり将来晎物反纫が生ず ることる教濾される.Albert（1965)はキヌターフプ 關節部の血管について詳絴に検索し，キヌタ骨病変によ

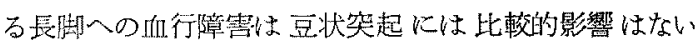
がファブミ骨に病蚠ある場合には豆状突起部が障害さ れるとのベている（因 8)。又小出（1965）はขチ骨

\section{图 8}
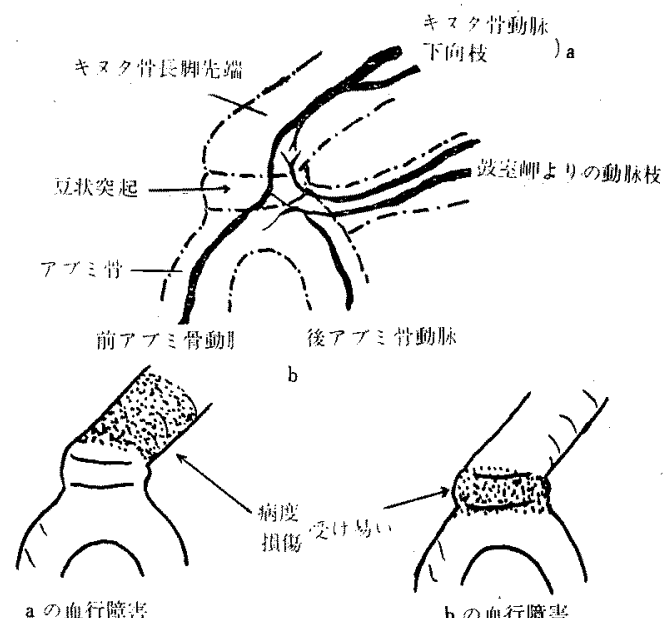

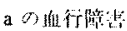

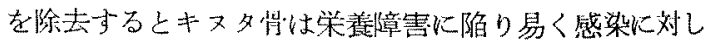
抵抗力を㳦ずるが，キ又夕骨を除去した場合ッチ骨は艺 れ程影響をらけないことから，キ又夕骨を残存せしめる 場合可及的にッチ骨も残存させるべきであると，更に後 藤（敏）（1966）は広い見地加ら含気化理論より耳小骨 の将多は中或骨壁とは别に考えるべきであり，一種の修 復過程にあると見做され得るものでコルメラとして利用 することに支障はないと、驿は Oesterle (1933) Wust. row (1954) は組織学的観点から耳小列は特䛈な骨構造 を有していることを指適している，しかし病理組織に就 
いては一般の骨に比し著变がないと言われている。一方 組織化学的㭘索で山本は Alkali-Phosphatase, AcidPhosphatase, Succinic-Dehydrogenase, Glycogen $の$ 染色を行い，所謂骨管腔に陽性のことが多くこの部位で 代謝が盛んK行われている事を推測し，吉田（1965）も これを深く検索し同様な成績を得ている。これらの組織 化学的検索はその発達と共に今後更に詳細な成績が期待 される。

以上は耳小骨の病変及びその取扱い就いて参考炕な る事項であるが，次にこのような耳小骨に括ける接合， 即ちッチ骨アブミ骨接合 (Malleostapedioexy) キヌタ 骨アブミ骨接合 (Incudostapediopexy)，あるい性又ッ チ骨キヌタ骨によるコルメラ及び人工材料化よるコルメ ラ利用に関しては更に次の伝音機構が問題となる。

b）中耳の伝音機構との関係就いて

中耳の伝音機構に関しては, Helmholtz (1868) は疑 膜の振動が内耳に伝わる際耳小骨は全体に振動し一種の 体積運動を行うと考学たが, Swart, John, Müller は 体積運動ではなく耳小骨を伝わる粗密波䡃によるとし た. 又 Politzer, Kessel, Kobrak 等休 Helmholtz の. 説にのつとつている.しかし Békésy（1936）は詳細な る契験の結果，低音に対しては所謂 lever action 様の 渾動であり高音に対しては縦軸の周りの動摇渾動を゙行う としている.今日では耳小骨の楨杆作用は impedance matching trasformer という考优迄すすめられ，又電気 音響学的方法で耳小骨の振動についても詳細な検討が Olson，恩地等によつてなされ，その振動が複雑なもの であることが䛠明されている。しかし理論と实際とは必 ずしも一致せす，臨床的には次の説が参考になる．即ち Lawrence, Wever（1950）によると，病的伝音障害怯 中耳伝音障害で $20 \mathrm{db}$ の損失に值し，鼓膜の变化で 10〜20db の損失に值すると.Wullstein によれば】型 の術後聴力は Odb に復し, 又正常鼓室腔を有する II 型 及び残存アブミ具が有効な lever action を有するなら ば，術後の聴力損失は $2.5 \mathrm{db}$ にすぎず，N型では20～ $30 \mathrm{db}$ の損失になるという。. Dingley（1955）はキヌタ 骨消失例の聴力損失の大なるを強調している，Johansen (1948) は中耳伝音の变化は質量, 弾性，摩擦の絹 合炕上るものであり，質量增加ては高部障害をふくし， 弾力低下では低音障害を生ずると. Stenger (1962) も 同様中耳伝音を，連鎖要素 $(\mathrm{K})=\frac{\text { 弹力 }(\bar{F})}{\text { 質量 }(\bar{M})}$ という 式を仮定し質量增加による $\mathrm{K}$ の擜少は高音部の障害
をきたし，質量增加 し弾力低下で $\mathrm{K}$ が小さくなると $1000 \mathrm{cps}$ 以外の障害をきたし，前者は Stapedectomy の状態であり，後者はフブミ骨の Interposition の状 態，即ち卵円空と植皮升の間にコルメラ等を䈯いた場合 に相当すると考光た。 Prubot はコルメラ効果につい

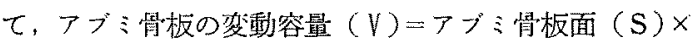
アブミ筲板変動価 (d) を仮定し V を生理状態内で 可及的に大きすする事が望ましいとし，アブミ骨の 形心最む近い円錐形のコルメラが最も良いと述べ ている. Beickert (1966) は Johansen (1948) の $\mathrm{I}=\sqrt{\mathrm{r}^{2}+\left(2 \pi \mathrm{f} \cdot \mathrm{m}-\frac{\mathrm{s}}{2 \pi \mathrm{f}}\right)^{2}} \mathrm{I}:$ インピーダンス, $\mathrm{r}$ : 摩摖, $\mathrm{m}$ ：質量， $s$ : 弾力の硬さ， $f$ : 振動数の仮 定の式が参考になるとし，伝志障害の場合の理論值山次 の如くなるとしている. 即ち1）耳小骨連鎖は正常で竦 膜穿孔のみの場合は，気導損失は $10 \sim 20 \mathrm{db} ， 2)$ 鼓膜 正常で連鎖に欠損ある場合（キスタ骨欠損など），気誉 損失は 50〜60db，3）政膜禁孔，耳小骨の連鎖欠損の

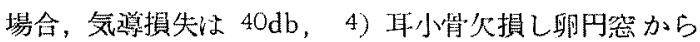
の聴力, 即ち W. N 型心相当与る場合，気導損失は 28 $\mathrm{db}, 5)$ コルメラ利朋，W. 目㕛耳小得連鎖の結合硬化 の場合，気導損失は $2.5 \mathrm{db}$ ：とのべ,更に蹦床的の伝暗障 需として次の4つをあげている．即ち1）外耳道閉塞の

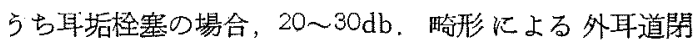
鎖の場台，50６0db の気導損失をきたし，2）耳管閉 塞の場合弾性硬化型 (elastischer Versteifung) とし て低音部の気導が低下し，鼓室に渗出液貯溜の場合，弾 性隇舞型（Dämpfungtyp）として高音部の気導が低下 乙更にこれらの混合型があるとし，3）外傷や桨症性変 化後の遗残物（Residuen）に上る伝音障害の場合 a) 癋着のみの場合， $40 \mathrm{db}$ 前後迄の気学損失をきたし， b ) 鼓膜穿孔するも耳小骨連鎖が保持されている場合， $2000 \mathrm{cps}$ 《比較的良好飞保た机 $10 \sim 40 \mathrm{db}$ の気導損失 をさたし，c）鼓膜穿孔と耳小骨連鎖不全の場合 30〜 $60 \mathrm{db}$ の気導損失をきたし，d）瘦孔存在し第 $3 の$ 空 となる場合，低音で 7〜 $17 \mathrm{db}$ ，高音で $5 \mathrm{db}$ の気導損失 をきたし，4）聴力改善手術の場合 W. I 型は $5 \mathrm{db}$, W. I型，型は $10 \mathrm{db}$ W. N型は $20 \sim 30 \mathrm{db}, W . V$ 型 は $30 \mathrm{db}$ ，小豉室形成は $20 \sim 30 \mathrm{db}$ の気導損失俩し，

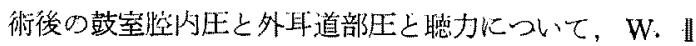
型のキヌターアブミ関節が軟部組織の場合, 鼓室のEが やや大きい方が聴力良く，W．目型の場合はむしろ鼓空 は陰压の方が良いと述べている，以上 Beickert の陻休 
的な考光方も大いに参考になる。

以上の伝音理論む参考にして著者の臨床例を分析し， 理論と実際とを加味恰傠するならば，より一層有意義な る成果を斉らし得るものと考えられる，即ちW，I型 に就いては伝音理椧上あまり問題となら始が，W．【型 例では所謂橋部は可及的に残存させた方が良く，又残存 鼓膜は使用可能な限り利用する方式が理論的にも臨床的

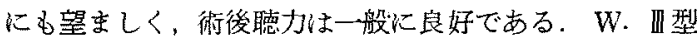
に就いては lever actionの保持が絶対に必要であり， このためにはフブミ骨の生活力之新生鼓膜の位置，祭張 度等を充分教慮しなければなら奴と考它られる。耳小骨 連鎖補修特に Malleostapediopexy, Incudostapediopexyに就いては，可及的に正常耳小骨連鎖に近い状態 とし槙杆作用が最も有効に働くよら解剖並びに生理学的 観点より充分心掛けるべきである。

c）支柱（コルメラ）使用に就いて

（1）耳小骨のコルメラ利用：この報告はZ̈̈̈llner (1955), Hall \& Rytzner (1957), Bell (1957), Wustrow (1958), 後藤 (修) (1960), Farrior (1960), 西端 (八), 高原, 黑住, 森本, 本多 (1960), Rubinstein (1964) 等があり，又教室の橋本教授等のものるある. 代表的なむのは，Hall \& Rytzner のもので，これは ッチ骨又はキスタ骨を利用するがいずれも卵円空は解放 せず膜様結合織，あるいはフブミ骨板残存（時に萎縮し ているものもある）例行う，欠点として炎症の存続が 推定されること，又異物反応ありとする説もあるがその 予防として全身及び局所を考慮した各種の莧剂投与方式 が实験考案され渐次効果的な方法が得られつつ古る。 又 不快な合併症としての疹着も自家骨のため組織反応も比 較的少なく術後の処置（通気法，副腎皮質ホルモン，各 種ビタミン剂等その他の薬削又術時局所㨂入のオイルワ ツクス等)を講ずればこの後遗症は從来より一層軽減し 得ることがでさるであるら，以上自家耳小骨利用の際々 の耳小骨の病変の程度の判定を厳密に行い残存耳小骨の 安定を良くし術後の吸収等を防ぐために筇膜等で被包す るとか，あるいは形の調整時可及的に粘膜骨膜を保存す べきである

（2）自家組織のコルメラ利用：自家骨片，軟骨，結 合暂脂肪塊等があり，それぞれ適当な大きさ，形に調整 した上耳小骨欠揁例に利用されるが，術後の萎維，消 失，肥厚，癒着等の後遗症を防止する上ら処置すべき で，そのため筋膜，軟骨膜，骨膜等で被包することによ りある程度前記捘遣症を防止し栄荃補給が保持され得る
と考えられる，この事は著者等の臨床実験成續からも踾 明されている. Heermann (1962) は軟骨を巧みに細工 調整し利用しているが，伝音構成の良好化という点では

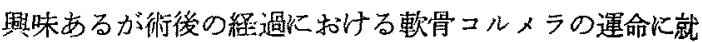
いては幾分の疑問が残る。軟部組織の利用は Stenger の理論からすれば最も不適当であり弾力少なく、且つ䫅杆 作用む殆んどないと思われるが Schuknecht (1960)の 報告にもある殆く術後経過中に痗痕化や結合織の硬化等 が起る可能性もあるので，コルメラ効果をだし聴力む激 進的に好転することも期待されるので再考を要するもの と思わ礼る，著者の結合織脂肪塊を利用した1例は，術 直後は聴力の改善を認めなかつたが術後 3 月頃から $30 \mathrm{db}$ 以内に安定し 1 年以上絟ても聴力 $27 \mathrm{db}$ と好結果 を得ている．即ちこのことからしてる䡆部組織利用の際 以経過観察が特に必要であることを裏書きしている。

（3）異種綃織のコルメラ利用：他種動物の骨より軟 部組織を融解処理し生物的学性質を失うことなく且つ免 疫学的にも刺战が少ないことから独乙で牛骨より精製さ れた所謂キールボーンが利用されている。著者の 1 例生 局所に異物反応なく術後 $30 \mathrm{db}$ と良好な結果を得てい るが，他に乳様洞充買に使用した 2 例に就いては 1 例は 明らがキールボーンによる異物反応と思われる反応が 認められた。

（4）人エコルメラ：こ机はポリェチレン,ナイロ ン、テフロン，ステンレススチール，タンタルム，白金 等が応用されているが，最も広く利用されているものは ポリエチレン細管である。ポリエチレンは Oppenheimer (1952), Bering (1955) により外科で手術時に利 用されたが，耳科としては Shea (1958) がはじめて利 用，ついで Myer (1960) Guilford (1958), Sham. baugh (1962), Goodhill (1963), Lindsay (1964), Harrison (1960), House (1960) 等の報告があり。テ フロンについては Shea, Goldmann (1962), Austin (1962), Arnold (1962) の報告があり，特に Gold. mannはホリエチレンょりすぐれていると指適してい る.タンタルムワイヤについては Burke (1940), Carney (1942), Babcock (1947), Lockhart (1952) Remine（1957）等により外科で利用されたが，耳科的に 法 Schuknecht \& Oleksiuk (1960)により初めて利用 された。しかし耳硬化症が主で，かかる金属は中耳炎の耳 小骨との接合については疑問が残り，又コルメラとして は粗な表面と硬さに不安がある，同様なことがステンレ ススチールに就いても言える，ステンレススチールワイ 
ヤーは Krupp (1940) により (18-8Mo)；(モリブデン 2〜4\%) のステンレススチールが, 更に Pratt, Gyne (1942), Bobcoch (1947) に上り外科で利朋されたが, 耳科的に泣タンタルム同様 Schuknecht (1960)により 初めて利用された．以上のコルィラについてアメリカで 一般に使用されているものは，Panthony（1963）によ れば, (1) ポリエチレンは, ポリエチレン90で $7 \mathrm{~mm}$ の長さ 0.050 インチの径即ち 15 ゲージ (Clay, Adams) (2) テフロンは $7 \mathrm{~mm}$ の長さ, 0.045 インチの径 (Richard), (3) タンタルムは 5.0 Tantalum で $7 \mathrm{~mm} の$ 長さに0.005インチの径のものを6本爸りにしたすの (Ethicon), (4) ステンレススチールは5.0 ステンレス スチールで No.36 を7mm の長さに0.005 インチ径 を6本捴り (Richard) が使用されている. 以上の他に Ehmke（1964）の白金使用の報告むある．

(5) 以上各種 コルメラの利用に就いて： Stenger Prubot の理論や Prubot, Schuknecht のコルメラが 参考になるが，一般にコルメラ利用時その伝音性に就い ては, 質量, 弾力, 抵抗の関係が術後の鼓室腔の広さ形 態とコルメラの質, 形, 更に手術術式と関与乙極めて複 雑である，この点に就いて奥野 (1956)，确部 (1956) によると質量は小さい方が伝音性は良く，又形は細い場 合 $4000 \mathrm{cps}$ 以下の伝音性が艮くなり，太い場合はむし ろ $4000 \mathrm{cps}$ 等の高音の伝音性が良くなり，新生䚳膜に 対してはコルメラ接点は可及的に中心がよく，敨室腔の 広さは広い万がよいと、しかし鼓室腔の広さに就いては 小さくても伝音上支障ないとの説もあり一様でない，著 者の症例では同一条件の場合政室腔心厇い力が聴力は良 好であつた。このため残存アブミ骨頭部にコルメラをは め可及的比鼓空腔を広くする術式も試及その成續は67\% で汪活满足すべき結果を得た。即方こ机は広い鼓室腔上 有効な lever actionの結果と考况られる，しかしW. 四型のアブミ管健全例の改善摔 $80 \%$ には及ばなからた。

（6）コルメラ使朋時の局所の影響：Wullsteinは 初期には合成樹脂系のコルメラを濑用した括もあつた が，異物反応が強いので見在は使用せず，Zöllner も自 家組織の方が良い上. Stengl, Hohmann (1964) は猫 の奏験で耳小骨をコルメラとした場合，2週から4ケ月 で, 又猿の帮験では3ケ月から9ヶ月で漸次 Periostal bone 飞置換されるがその耳小骨の構成成分虫保持され ていたと. Bellucci and Walff (1961) \&又猫の快駼

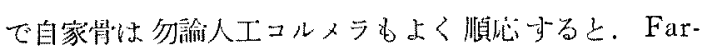
rior, Richter (1958) はキヌタ捎のコルメラは良好な経
過をとると. Hall \& Rytzner (1960) は組織学的に追 及し耳小骴はよく順心するとのべている。

人工コルィラに就いては：即ちポリェチレンについ ては Sooy (1961) はよく順応すると.テフロンについ ては，Goldmann (1962) の猫の実験でポリエチレン, 白金には異物反応を認めたがテフロンの場合は無かつた 之. 又 Schuknecht は金属コルメラは異物反応が殆ん どなくよく順応すると. 同样 Hohmann (1964) はねず みの実呀でポリエチレンコルメラは $1 / 3$ に線維症の反応 を認奴が、ステンレススチールやテフロンでは組織反 応は認められないと. Lindsay (1961) はわずがポり エチレンに異物反応を認めている。

Harrison (1960) は病理学的研究で人エプロテーゼの 異物反応を検索し，異物反応を吠め大例に就いて，(1) ポリエチレンの場合非炎症性巨細胞をるつた線維組織 を，(2)テフロンの場合巨綀胞と軽い慢性炎症を伴った 線䧽症を，(3) タンタルムの場合硝子化を伴 ら線維症 を，(4)ステンレススチールの場合線維症を認めるが巨 細胞を有する炎症性变化は認められなかつたとし人工ニ ルメラ使用に批判的である. 又 Anson は耳小骨の栄養 㧈管飞障害ある人工コルィラの利用に対して警告を発 し, 小出は炎症性変化のある場合は人工コルメラの利用 は不適当であるとのべている．以上の如く人エュルメラ の異物反応に就いては様々な説がある。

(7) 接着郕(耳小骨連鎖補修成形又コルメラ使用の 際補助剤として使用される)に就いて：これには (1) $\boldsymbol{\alpha}$-Cyanoacrylate 樹脂モノマーを主体とする無溶剂型 の接着郕上，(2) Methyl-2-Cyanoacrylate からできた ものに可撓性，弾力性を持たした EDH Adhesive の 2 種が使用されている。出は EDH Adhesive に就い て，炎怔性变化ある時は不適当であるとのべている，著 者の症例小数例であるがこの2 種の接着用中，前者は接 着性が速效であるが可暁性弾性を欠さ，これに対し後者 は接着硬化時間が長くその挼着効果が不確寒の恐れがあ るが，可撓性と弾力を有する点及び組織反応も少ない点 で前者より鼓室成形術には適していると考えているが， なお゙ネだ完全なものとは云えない，

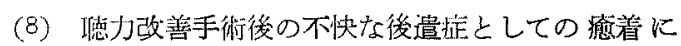

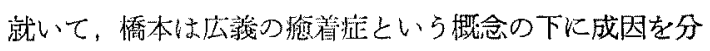
粸し，それに刘する処监が必要であるとのべている，即 ち一般的分類と病理組緎学的分類から恰討を加えている

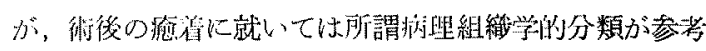
になる、それによると，(1)骨膜からの線維来細胞とそ 
秃による線稚性瘉着，(2) 分泌物，膿瘍の機質化による

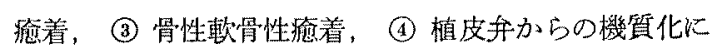
よる癒着の4つをあげ，ての防止には適当な術式及び術 後処置と共に表9の如さ楽斉療洰で好結果が得られると のべている．著者の症例においても橋本教授の指尊の下 で術後の瘉着防止に可成の成果があげられている。

\section{表 9}

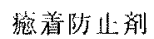

1) 消桨剤及び各種ビタミン郕特に $\mathrm{B}$ 群, $\mathrm{C}_{37} \mathrm{H}_{38} \mathrm{O}_{6} \mathrm{~N}_{2}$ (セファランチン)

2) 線稚䇣折出防止都

アドレノクローム系止侐阂

罠罢皮質ホルモン凪

3) 線䧽融解成

フイブリノリジン、ヒアルロニダーゼ，人パリン

4) 結合螕增殖抑制郕

副腎皮質ホルモン用，コンドロイチン硫酸

5) P.V.P. デキストラン (Chate 1964)

6) Silicone oil (Prachnabmoh 1964)

7) D.M.S.O. Dimethyl sulfoxide (Jacob 1965)

d）手術例の検討

（1）W.I型に就いてては前述の如く術後の癒着以外 程んど問題とすべき点は認めなからた。

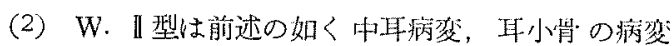
及び策善補給更に新生鼓膜等が間題となる症例で，可及 的に病变の消退した適心期飞手街を施行し，中耳腔の淀 丝除去に際しては特に耳小骨の被膜を含めて栄荃障害の 少ない術操作に留意し正常の伝音構成の保持を試みたも のである. 即号眧和 35 年迄は術後聴力 $30 \mathrm{db}$ 以内のも の78\%で昭和 36 年以後は $80 \%$ と良好な成績が得られて いるが，これは伝音棈成上最子合目的と思秃る方式を 考慮した結果と思われる。しかしなお $20 \%$ 近くは改善 が得られなかつた，その原因に就いては前述の如く稩菌 相の種類及び感受性の悪性度の高い例及びそのための再 発，次いて病栄部の除土不全，新生鼓膜の穿孔，Lapencholesteatoma，痊着等多含めて中耳腔の不良な形態

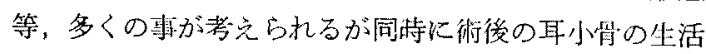
力及び機能といら点で牫存不谪な病变耳小盈を残存せし めたための不成功例考觉られる、特にキヌターアブミ

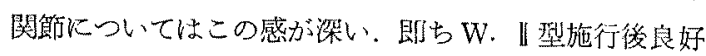
な結果が得られず再発のため再手術が行われた症例を检 討すると，此較的良好な中耳腔に拘らずキヌターアブミ

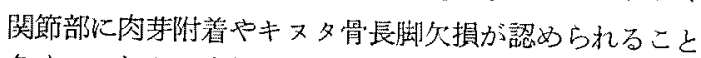
多く，これらの症例は前回手術特キヌターアブミ門節不
全例が最も多かつた．同様のことはキヌターアブミ関節 不全例に対しキヌタ骨をずらしてキスタ骨アブミ骨接合 Incudostapediopexy を施行した症例は，わずか筋膜で 被包したもののみが放善されたにすきなからた事と，か かる操作をする或なく関節部のみを補修成形したものが 好結果を得ていることからす明らかで，W. I 型で当然 好結果が期街されるに拘らず㯖力改善せぬ例に括いて は、その原因は祭志すべき病的耳小骨を残存させた事，特

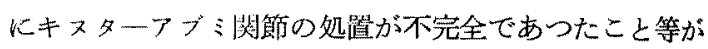
推測され得た。このことから省時耳小骨を牫存ざせる場 合，先ずその病変の程度を手術用顕微鏡強㹡大下 (16x $\sim 40 \times$ ） に精查し残存使用の可否を熟虑し，その判定に 従つて術式を考案する事である。即らキヌターアブミ関 毁不全例に㤼 801 b の如く耳小骨の栄盖補給の障 害を可及的に少なくしつつ関節不全部を補修することが 望むしい：しかし，これと同時に耳小骨自体の本来の生 活力に就いても考慮すべきであり，この点に就いては更 に今後の病理学的梌柀が必要であるう.

(3) W. 四梨に就いては

前述の如くアブミ骨煡全例は福变，変位，肉军結合裁 に埋没等のある不全例に比し術後㯖力の改卧は非常に良 く,W. II 型上程えど同程度の好結果を得ている。しか

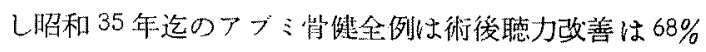
で炤和 36 年以後の $80 \%$ に及ばない、これは昭和 36 年 以後残存アブミ骨の詳細な检索之有効な lever action

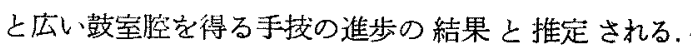
即ち伝音理論で述べた如く W. 四 型でアブミ骨健全な 場公有効な lever action が新生鼓膜と卵円空間に働 た場合 Wullstein は噹力損失は $2.5 \mathrm{db}$ にすぎないと のベているが，著者の W. III型の德力改善例を検討す ると，ほぼ2つの群に分けられ，その1つは Wullstein の云う如く殆んど正常火近い術後埴力 $5 \mathrm{db}$ 前後の6の と，他は術後㯖力 $20 \sim 30 \mathrm{db}$ のものとであつたが，こ の相違は所謂 lever action の効果によると思われる. 術後の経過中の嘸力に就いて，一般にW.【型は術後 耳内タンポン除去し新生鼓膜が乾懆状態になる3週めの 㻥力と 1 力月後, 3 力月後, 1 年後の間には軽度の高音 部の改善があるたりで著変は認められなからたが，W. 四型例では全く一定してなく，術直後良好であつたすの が6カ月後急に不良になる例もあり，この原因として新 生鼓膜とアブミ骨の接合不全が考えられる. 又逆に術直 後それ程奨明な聴力改善をみないに拘らず，3力月6力 月と汧炏改善され Odb 近く迄になる例むあつた。この 
理由は薄い新生鼓膜とアブミ骨と卵円空の間に最も効 果的 lever action が成立したためと考えられる。しか し一般飞 $1500 \mathrm{cps} 2000 \mathrm{cps}$ の Gipfel 形成の聴力像を 示すものが多く，その解析に関しては今後検討すべき点 を多く残している。文フブミ骨不全例化就いてはとの利 用の可否を精査し，生活力及び機能が不全と推定される

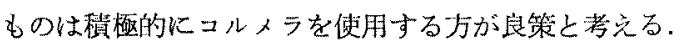

（4）W. N型とコルメラに就いて：W．N 型は炎症 性変化強度で時に活動性であり，再手術例も多く術後聴 力はあまり良好でない，しかし病栄除志の比較的容易な 例に括いては積極的にコルメラを利用し伝音構成の改善 を計るべきである。この際コルメラとしては残存耳小骨 を利用できることが、最も望をしいが，耳小骨をコルメ ラとする場合被膜の損傷を少なくし栄養障害を防ぐこと と，有効な lever action を得るよう設置することとの間 には矛盾がありこの調和が問題となる。著者は先づ相 骨の病变の程度の検索後利用可能なものに対しては栄堭 血管を損傷せ双上ら. 又骨被膜を可及的に残存させコル メラとして利用するが、ソチ骨では比較的容易にできる 場合があるが，キ又タ骨では摘出し，形を適当に調整後 再㨉入等で栄義血管を障害することが強い，これに対し ては筋膜, 結合織等で被包し術後の鼓室新生粘膜からの 栄着補㭘が可能と考えられる迄血液体液を呚収し易い㖹 膜からの栄養補給を考慮した。この事は表 8 キヌタ 骨をずらし Incudostapediopexy 例又関節補修例更に Malleostapediopexy 例，耳小骨コルメラ例で筇膜被 包例が耳小骨の術後の不全化を防止乙聴力改善を得てい る事から容易淮定できる。

次ぎに人エコルメラ使用例に就いては活動性の病变の ないものが望ましいが，一般にはコルメラ使用例は病変 高度で且つ活動性のものが多く，又コルメラの安定化に． 困難さがあり，更に卵円空の機能にる問題がある、著者は 前述の如く病変についてはその除去が可能であり且つ病 変の活動性に就いては術時術後の処值で顧慮すべき問題 はないと考えている，卵円空部については前述の如くフ ブミ骨板は残存している事多く，消失しても膜様結合織 がアブミ骨板様の機能を有している事から，卵円空に手 術操作を加觉る事なく，主としてボリエチレンコルメラ を使用した，次ぎその安定については，ジェルホームは 殆んど利用せずクロスバーか残存鼓索神経を利用した。 クロスバーは安定よく lever action に支障ないものに 好結果が得られた。

コルメラと皮弁の接触部に就いては、コルメラの形態
が問題となるが，図 7 中の金状のものと円板状のものを 用いたが，前者は皮弁とのずれは少ないが，鋭利な部分 あるため穿孔の因となる恐れあり，後者は皮升との間に ず机が考觉られるが断端は釚のために穿孔の恐れなく一 概には云え妨，やや円板状のものの方が良い上らであ つた．しかしいずれの場合もコルメラを直接に皮弁に接

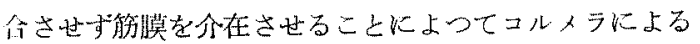
術後柕孔は可り防止する事がでさた。

キールボーンに就いてはコルメラとしたものは1例し かなく，この症例では好結果を得たが，乳様洞充買に用 いた 2 例中 1 例化は明らが異物反応に上る脱落があ り，今後免疫学的にも再検討要するものと思古る。

タンタルム，ステンレススチール等の金属コルメラは 接力弹力の点で慢性中耳炎例の手術に利用するよりむし 万耳硬化症の如き例比適応さるべきであると考光てい る.

(5) 接着剂及び瘉着防止丼比就いて

耳小骨間の接合，関節補修更にコルメラ使用時に EDH Adhesive を使用したが，小出の云う如き組織反 応はなく良好な経過をとり接着効果も充分期待できた。 これは各種の消炎济及び抗生物質等の併用によるものと 考学られる.今後更化動物実駼を含めての検索が必要で あるら、文癒着防止剂については術時の手挍と術後の処

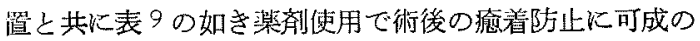
効果があるものと考占ている。

\section{第 VI 章 結 論}

中耳の慢性疾患あるい情天後天異常を有するもの で，乙かも伝音系障紫を是する症例に対して昭和 29 年 上り昭和 41 年に至る 485 耳の手術処見, 手術方式及び 術後の経過に対して，各種の検討を扣へた。

特㳊残存耳小骨及び人エュルメラ利用例に対し理諭的 並びに臨床的両面上り锥察し，その効果的な術式及び術 後の治膫涼いて総括し次の如き結椧老得た。

1）W. I 型施行例飞就いては病变少なく耳小等の残 存は可能であり，ただ術後嘴着を防止するゃら術時適切 な処置と術後の痽着防止処置及び薬济使用で好結果が得 られる.

2）W.【型施行例飞就いては，手術時手術用顕微鏡 強掋大下で特に耳小骨を慎重に检甞し残存可能な場合 (a) キヌターアブミ骨関锦健全なら術後聴力は良好で あるが，（b）関節不全の場合約 10\%術後結果が不良 で，その原因は関節不全のためと推定される故に，耳小

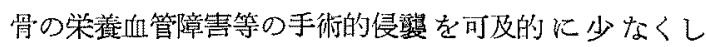


て関節補修成形を行ら事で好結果が得られる。

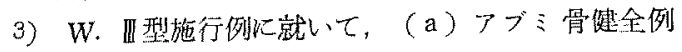
には lever action 孝效果的にするよら手技に慎重であ つた例は好結果を得ている。（b）アブミ臂不全例は， 先ぶアプミ骨の残标の可否を精查し，残存不適の場全任 積極的にコルメラを利用すべきである。

4) W. N型施行例化就いて，詶後聴力改善例少なく 可及的にコルメラを利用すべきである.

5) コルメラ健用例に就いて、コルメラとしては自家 耳小筒が最も良いしかし耳小骨の利用がでさ婸合は 人工ヌルメラを肺いる゙，ポリエチレンが最も普遍的で

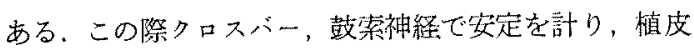
弁と接する部で鋭的な断端を少なくし且つ皮弁は筇膜で 異うらさせるのが最る良い結果を得る。人工コルメラに よる異物反応は術時病栄部の忘分な除去上術後の薬風を

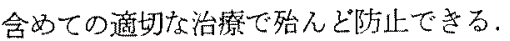

6)接着威は関節補修等に使用したが特にキ又ターア ブミ関節袺修で好結果が得られている。

7) 癒着は手術後の瘦痕治愈の一症状として重要であ るが反面又不快な後遗症として㙨能不全の状態である。

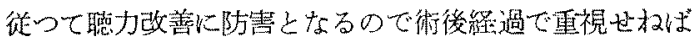
なら妨，瘉着防止処置と其に各種癒着防止薬郕とその 使用法に就いてかなりの效果を得ているが，今後更に考 慮せねばならぬ重要事項と考学られる。

8) 聴力改善手術時耳小骨は可及的に正常状態に残存

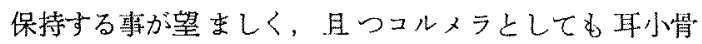
が利用可能の場合は最適であるが，耳小冎の残存の可否 及び利用に就いては今後その生活現象と生活力と含めて 病理組織学的に更に梌案すべきですると考えられる。

\section{䆖考文献}

1) Albert: The Blood Supply of the Long Process of the Incus and the Neck of Stapes. J. Laryng. \& Otol., 74: 964, 1965.

2) Anson, Harper and Winch: Intra-osseous Blood Supply of the Auditory Ossicles in Man. Ann. Otol. Rhin. \& Laryng., 73: 645, 1964. 3) Anthony, W.P.: Com* parative Study of Four Prosthetic Materials. Arch. Otolaryng. 78: 595, 1963. 4) Austin, D.F.: Present Status of Vein Graft Tympanoplasty. Arch. Otolaryng. $81: 20,1905 . \quad 5)$ Beickert P.: Gehör bei veränderter Schalleitung. Hals-. Nasen-, Ohrenheilkunde $\mathrm{Bd} .3$, Teil 22: 1198, 1966. 6) Bé késy, G.V.: Zur Physik des Mittelohres und Über das Hören. Akust. Jschr. 1: 13, 1936.

7) Ding. ley, A.R.: Some Limitation of Radical Mastoidectomy and Value of Early Conservative Surgery. J. Laryng. \& Otol. 69: 361, 1955.

8) Donalis: Histologisches und Pathologisches von Hammer und Amboss, Arch. Ohr.-, Nas.-, \& Kehl.- heilk. 42: 226, 1897. 9) Ehmke, O.: Platinum Stapedial Prosthesis in Middle-Ear Surgery. A.M.A. Arch. Otolaryng. 79: 54, 1964. 10) Goldmann, J.L., Nalebuff, D.J. and Druss, J.G.: Experimen. tal Observations on Prosthetic Material in Stapes Surgery with Special Reference to the Use of Teflon. Laryngoscope 72 : 169, 1962. 11) Good hill, V.: Theoretical Aspects of Stapes Mobiliza. tion. A.M.A. Arch. Otolaryng. 71 : 248, 1960. Grunert: Weitere Mittheilungen über die Hammer-Ambossextraction mit besonderer Rucksicht auf die Diagnose der Ambosscaries. Arch. f. Ohr.-, Nas.-, \& Kehl-heilk. 33: 207, 1892.

13) Guilford, F.R.: Tympanoplasty; Use of Prosthesis in Conduction Mechanism. Arch. Otolaryng. 80: 80, 1964. 14) Hall, A. and Rytzner,C.: Stapedectomy and Autotransplantation of Ossicles. Acta. Otolaryng. $47: 318,1957$. 15) Hamberger and Wer. säll: Vascular Supply of the Tympanic Memb. rane and the Ossicular Chain. Acta Otolaryng. 62:923, 1953. 16) Harris, A.J.: Experimental Findings Following the Stapes Replacement Procedure. Laryngoscope $71: 131,1961$. 17) Harrison, W.H.: Prosthesis in Tympanoplasty. A.M.A. Arch. Otolaryng. $71: 437,1960$. 18) Heermann jr. E.: Trichterförmige Fascienplastik des Trommelfells aus mehrenen Stucken mit Knorpelbrucke zum Stapes nach Radikaloperation des Ohres und das Gehör bei dickerem Trommelfell. Arch. f. Ohr.-, Nas.-, \& Kehlk.-heilk. 180: 556, 1962.1 19) Helmholtz: Die Mechanik der Gehörknöchelchen und des Trommelfells. Arch. f. die Physiologie 1868. 20) Hohmann, A., Hilger, J.A., and Car ley, R.: Fate of Implants in Rats. Ann. Otol. Rhin. \& Laryng. 73: 791, $1964 . \quad 21)$ Hough, J.V.D.: Incudostapedial Joint Separation Etiology, Treatment and Significance. Laryngoscope 64:614, 
1957. 22) House, H.P.: Unfavorable Results of Stapes Mobilization Surgery. A.M.A. Arch. Otolaryng. $71: 313,1960 . \quad 23)$ Hyer, D., Schlosser, W.D. and Winchester, R.A.: The Stapedectomy Procedure of Shea. A.M.A. Arch. Otolaryng. 72: 295, 1960.24$)$ Johansen: Relation of Audiograms to the Impedance Formula. Acta Otolaryng. Suppl. 74: 65, 1948. 25) Koide: Foreign Materials in Tympanoplasty. Ann. Otol. Rhin. \& Laryng. $74: 1055,1965$. 26) Lawrence, $M$. \& Wever, E.G.: Recent Investigations of Sound Conduction. Ann. Otol. Rhin. \& Laryng. 59: 1020, 1950.

27) Lindemann: Some Histological Examinations of the Incus and Stapes with Especial Regard and their Vascularization. Acta Otolaryng. Suppl. 188 : 319, 1963. 28) Lindsay, J.R.: Stapedectomy in Fat Graft Polyethylene Strut. Arch. Otolaryng. 80: 128, 1964. 29) Lindsay, J.R.: Histopathologic Finding Following Stapedectomy and Polyethylene Tube Inserts in Man. Ann. Otol. Rhin. \& Laryng. 70: 79, 1961.

30) Ludewig: Über Ambosscaries und Ambossextraction, ein Beitrag zur Aetiologie und Therapie der chronischen Mittelohreiterung. Arch. f. Ohr.-, Nas.-, \& Kehl.-heilk. 29 : 241, 1890. 31) Manasse: Handbuch der Pathologischen Anatomie des Menschlichen Ohres 135, 1917. 32) Nager, G.T. and Nager, M.: The Arteries of the Human Middle Ear with Particular Regard to the Blood Supply of the Auditory Ossicles. Ann. Otol. Rhin. \& Laryng. 62: 923, 1953. 33) Oesterle, F.: Über den Feinbau der Gehörknöchelchen und seine Entstehung. Arch. f. Ohr.-, Nas.-, Kehl.-heilk. 135: 311, 1933. 34) Portmann, M.: Tympanoplasty. Arch. Otolaryng. 78: 2, 1963. 35) Prubot: 60e Congrés Français d'Oto-RhinoLary. 1963. 36) Rubinstein, M., Korine, E., and Eviatar, A.: Malleostapedial Transposition of Middle Ear Surgery. A.M.A. Arch Otolaryng. 80: 38, 1964. 37) Schuknecht, H.F. The Metal Prosthesis for Stapes Ankylosis. A.M.A. Arch. Otolaryng. $71: 287,1960 . \quad 38)$ Shambaugh, G.E.: By-Pass Surgical Techniques in Stapes Surgery. A.M.A. Arch. Otolaryng. 76: 542, 1962. 39) $S h$ - ea, J.J.: Teflon Piston Operation for Otosclerosis. Arch. Otolaryng. 76:516, 1962 . 40) Sooy, F.A. Barrios, X., Hambly, W., and Burn, H.: A Clinical and Laboratory Evaluation of Polyethylene tubing in Middle-Ear Surgery. Ann. Otol. Rhin. \& Laryng. 72: 191, 1963.41$)$ Stenger, H.H.: Über den Schalleitungsbedington Hochtonverlust nach der Stapesplastik mit 2 Textabbildungen. Arch. f. Ohr.-, Nas.-, \& Kehl. heilk. 180: 573, 1962. 42) Stengl T.A. and Hohmann A.: Experimental Incus Transposition Arch. Otolaryng. 80: 72, 1964. 43) Wullstein, H.L.: Principles of Tympanoplasty. A.M.A. Arch. Otolaryng. 71 : 329, 1960. 44) Wullstein, H.L.: The Surgical Restoration of Hearing in Chronic Otitis Media and its Audiological Basis. Ann. Otol. Rhin. \& Laryng. 67: 952, 1958. 45) Wustrow, F.: Über den Knochenfeinbau in Hammer und Amboss. Zsch. f. Laryng. Rhin Otol. u. Grenz. 33: 206, 1954. 46) Zöllner, F.: Tympanosclerosis. Arch. Otolaryng. 78: 538, 1963 . 47) Olson: 音䅨工学 (西巻正太郎訳) 84, 昭 36. 48) 井上（正）：慢性

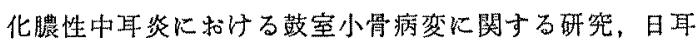
鼾，61：876，1958（昭 33)。49）猪他：鼓室成形 術西型の術㣪聴力について，Audiology 7: 101, 1964 (昭 39). 50) 岡部：耳摸型飞よる中耳质音器の笑 騟的研究，日耳鼻，64:1386，1961（昭 36）. 51）舆 由(兼)：慢性中耳炎における耳小骨病变について，耳 唉科，36：315，1964（昭 39）。 52）奥野：鼓室成 形術の层音系修復に関する研究（第1螎，第2 編)，日 耳奥，64:1583，1961 (昭 36). 53) 恩地：聴器 の伝音機满、日耳鼻，63：632，1960（昭 35）。54）

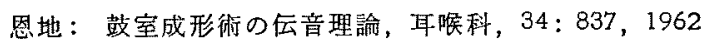
(昭 37). 55) 柏戸：耳小骨連鎖の機能に関する

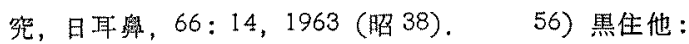
耳小骨, Polyethylene Tube, Tantalum wire による コルメラ形成，耳陮科，34:873，1962 (昭 37)。 57) 小出：敪室成形術の諸問題，日耳睤，68:589，1965 (昭 40)。 58) 五味：鼓室成形街に上る周波数移動

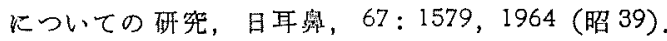

59) 後藤（修）地：鼓室成形術の発展の歴史, 耳㬋科, 34:816,1962（昭 37）. 60）後藤（修）他：政室 成形術後にお汀る高音障害についての考察，Audiology 
$7: 105,1964$ (昭 39)

61) 後藤（敏）監修：耳鼻 咽婙科学上巻，330 342, 1960 (昭 35).

62) 後藤

(敏)：慢性中耳炎に括ける局所病变の受取り方につい て，日耳舅，69:451，1966（昭 41).

63) 橋本:

鼓室成形術式の概要とその動向，耳㬋科，34:823， 1962 (昭 37). 64) 橋本他：敋室成形術，特飞 columella の工夫を中心として，耳率，10：207，1964 (昭 39）。 65) 橋本他：中耷真珠腫症における耳小 骨の変化について，耳喉科，36:797，1964（昭 39).

66) 堀内：中耳根治手街より得たる中耳炎症に和ける 小聴骨に就いて，日耳鼻，41：1405，1935(昭 10).

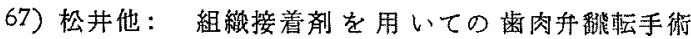
Coating 法に関する实鈳的並びに臨休的研究，歯界展 望，24：291，1964（昭 39）。 68）山本：聴力改善 手術，消炎汇関する諸問題，第 16 回医学総会シンポジ
ウ $厶 23$, 別冓，1963 (昭 38)

69) 吉田 (一)：僈 性中耳炎の軟骨部の病理組皎学的ならびに組織化学的研 究，日耳鼻，68：149，1965(昭 40)。

稿を終るに臨み，終始御㤵第なる御指導，御校閲 を睗わつた恩師榻本教授に深萁の謝意を表すると其 に，御助言御協力を载いた弓削庫太講師古内一郎講 所主びに教室員各位に感謝しるす。

本論文の要旨は，日本耳奥咽搌科学会第63回， 第 65 回総回並びに日本耳鼻咽喉科学会，第 42 回関 東地方会大会, 第 405 回関東地方会, 及び，第 5 回 オトマイクロサージヤリー研究会に夫ょ発表した。

（原稂到着 $=$ 昭和 41.8 .15 日） 